\title{
THE BIGGEST SURFACE MINING DISASTER IN POLAND AND ITS ECONOMIC RESULTS
}

\author{
KRZYSZTOF MAŁACHOWSKI \\ University of Szczecin, Faculty of Management and Economics of Services, POLAND \\ e-mail: krzysztofpm@o2.pl
}

\begin{abstract}
\begin{tabular}{l|l} 
RECEIVED & 10 December 2018
\end{tabular}
\begin{tabular}{l|l} 
ACCEPTED & 28 December 2018
\end{tabular}

JEL

CLASSIFICATION

L72, L78

KEYWORDS Salt mine, mining disaster, economic results, catastrophes, Wapno

ABSTRACT The aim of the article is the biggest surface mining disaster in Poland and its economic results. The accident occurred in 1977 in Tadeusz Kosciuszko Salt Mine in Wapno (at present in Great Poland region). Up to the 90's of the XX century, the society hadn't been aware about the catastrophe. Nowadays, it is still almost unknown. Wapno has never regained its prosperity. The study object is the hold-up problem in managing the natural resources (salt) and the socio- economic results for Wapno, Greater Poland region and Poland as a whole. The study methods are based mainly on observation because the author of the article witnessed the incident, the case study and the analysis of bibliography sources.
\end{abstract}

\section{Introduction}

In the second half of the 1977 , the biggest surface mining catastrophe took place in Wapno. It succeeded the predatory exploitation of a big quantity of salt dedicated mainly for export. In the night from 4 to 5 August, after the labor, in the Tadeusz Kosciuszko Salt Mine (Figure 1), water inrushed into salt excavations located at the third mine level. The catastrophe occurred in Gierek's decade. As it happened in the times of 'propaganda of success', the 
details of the catastrophe were almost forgotten. The media of that time hardly spoke about it. It had been a taboo up to the 90's of the XX century. Today, it is still remains unexplained. Wapno is a municipality in Great Poland region in Wagrowiec district. In the ' 50 , ' 60 and '70 of the XX century, Wapno was founded as miners' housing estate counting 3,000 of inhabitants.

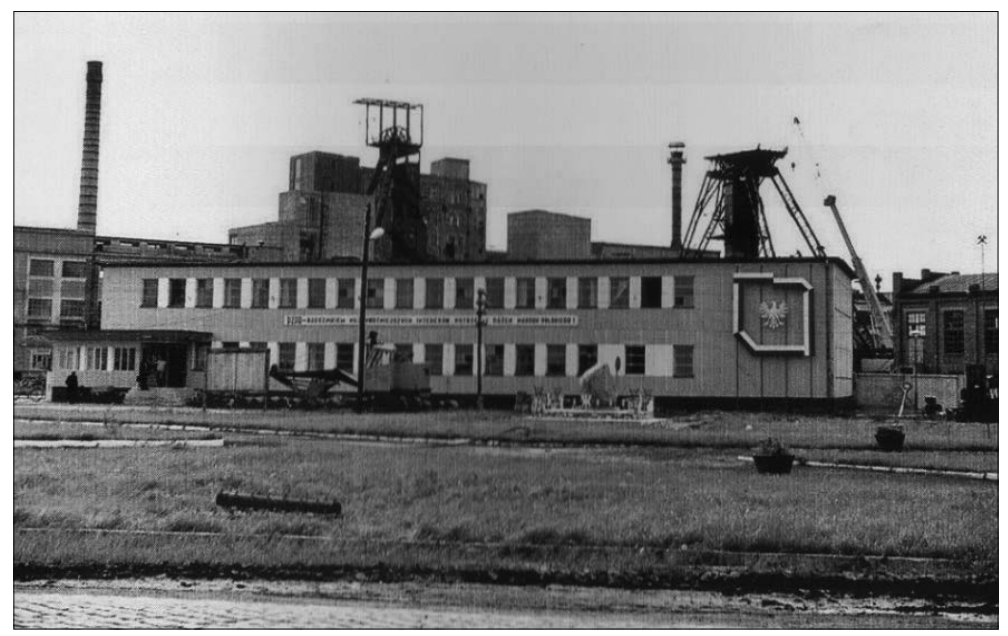

Figure 1. The Salt Mine in Wapno - August 1977

Source: Przesławski, Ryska, Wojciński (2011), p. 15.

\section{The outline of Wapno gypsum and salt mining up to the Second World War}

The most important minerals excavated at Wapno are gypsum and rock salt in form of diapir (salt domes) laying under gypsum (Muszyński, 1999a, p. 13). The formal mining activity started in Wapno in 1828 when Florian Wilkoński, the owner of the settlement begun the exploitation of gypsum deposits (lying just below the surface) by open-pit mining method (Muszyński, 1999b, p. 47).

According to the historical sources, the high quality gypsum from Wapno had already been used for the construction of many medieval buildings like Cathedrals in Gniezno and Poznan (Skoczylas, 2011, p. 78). In the XIX century, during the gypsum excavations, the traces of brine were discovered. At the beginning, around 200 tons of gypsum was mined per year and in 1850 there had been already about 5,000 tons (Łuczak, 1959, p. 115).

After the raw material excavations, it was transported to Nakło by Noteć where it was treated. In 1835 , the gypsum mill equipped with steam machine was constructed inside the mine. The gypsum treatment was then possible on the spot. In 1887, the railway line was built up (currently no 281) connecting Wapno with Nakło and Gniezno.

The gypsum excavations were done at three levels, one on the surface and two underground. The mine was prospering before the World War I where 20,000-25,000 tons of gypsum were excavated per year. 
In the next years, the production and investment works hadn't brought satisfactory profits and there was even a danger of bankruptcy. In 1929, The joint-stock Association sold the mine to Belgian Solvay company which was engaged in further works related to the mine shaft deepening. The works were interrupted by the increased water inrush and they were finally stopped in 1931. In 1933, they were so serious that Solvay was forced to close the mine (Boras, 1963, p. 63).

Paradoxically, the situation was favorable for Solvay as in that way it got rid of the concurrency as the company had already been in the possession of their own gypsum mines.

In 1869, in the territory of open-pit gypsum mine, while drilling a borehole, $2 \%$ brine was discovered 36 meters under the surface. Basing on that fact, Bolesław Moszczeński, the owner of Wapno obtained the permission to exploit /mining concession/the brine called Bolesław. In 1871, at the depth of 60 meters, the halite was drilled. The mining concession was obtained. It was called Moszczenno. In 1892, the German partnership Soolwerke bought the concession and executed new salt drill obtaining the third concession called Eintracht.

In 1907, two salt mines in Inowrocław were flooded. In the previous year, Solvay bought and renovated the Soda factory in Mątwy, close to Inowrocław. Because of the floods, Solvay was deprived of basic raw material (salt). That's the reason, it bought the halite mining concessions in Wapno and it started to elevate the mining buildings on its surface (Grabowski, 2013, pp. 141-142).

1911 was considered as the year of the foundation of the mine and the construction of the shaft Wapno. In 1912, after few months, the construction was interrupted at the depth of 100 meters because of the water inrush. There was a decision about constructing the second shaft 63 meters further. The final depth of the shaft Wapno II was 420 meters. It was opened in 1917. In total, 8278 tons of salt was excavated. The salt dome measuring $700 \times 350$ meters and almost 4 kilometers deep was exploited. In the times of the second Polish Republic, the mine belonged to Belgian company "Solvay Company in Poland". It was the time of its flourishing development. In the years 19281930, new salt processing factory (modern reinforced concrete salt mill) was constructed. The eight-story building is dominant, nowadays, in the Wapno landscape. In 1930, the mine had the highest number of salt excavated for the whole interwar period - 100,896 tons (Domichowski, Günther, Jankowski, 1963, p. 78).

The number of the mined salt was at that time managed by the Polish Salt Monopole which favorized its own mines. That's the reason why the mine couldn't always reach the full production capacity. It was the time when the work was planned for three days per week (worldwide economic crisis 1929-1933). Despite the fact that the highest profits obtained from the Wapno salt sale was on salt monopole side, the Solvay benefits were sufficient for investments in technical and social infrastructure like modern school complex that was constructed in 1935. In 1932, the steam winding engine of $450 \mathrm{KM}$ power was installed. In 1931, it was raised in the steelworks "Agreement" in Świętochłowice-Zgoda.

During the World War II, the mine was exploited on big scale. The Germans were aware about the good salt quality. The maximum of production capacity was reached. The electric switchboard was expanded. The external power supply and new electrical equipment were provided.

\section{The Wapno Salt Mine Activity during 1945-1977}

After the World War II, the company was nationalized and incorporated at first to salt monopole and then to Chemical Mineral Mining Association in Cracow. The industry was restored. The salt mining was systematically reinforcing. In the years 1950-1965, the Wapno Salt Mine was the biggest salt producer in Poland. The Wapno salt 
production constituted the half of the Polish halite production. In 1966, second mine shaft Wapno I was elevated. This fact like the renovation executed in the 60' influenced significantly the production increase which exceeded 400000 tons per year in the years 1967-1975. The historical high score of 462789 tons was reported in 1975. The high quality salt was exported around the world ( in particular to Sweden, Finland, Norway, Great Britain, Denmark, Nigeria, Czecho-Slovakia and Hungary). In that way, the precious dollars were collected in the People's Poland times. The excavated salt was also distributed in Poland. The number of mine employees was raising up. In 1968, the employment level reached 700 people and it was the highest in the history (Lisiecki, 2007, p. 62).

Thanks to the Tadeusz Kosciuszko Salt Mine, Wapno started to quickly develop. In 1956, the settlement obtained rights of miners' urban housing estate. In 1977, it counted almost 3000 inhabitants. The Wapno mine financed the construction of residential areas, public buildings and it supported the cultural, sport and educative activities.

\section{The mining failure in 1977 and its results}

The tremendous danger in salt mines is the water inrush from beyond the salt deposit. From the very beginning of the Wapno mine activities, the water constituted a big issue for the shaft construction and exploitation (Salt Mine..., 2018). In September 1971, the mine shaft Wapno I was in danger but it was managed thanks to the rescue operations. From August 1972, at the mine level III, in the chamber no 36, the inrush of water (2 I per minute) was observed. In September 1976, the water reached 7 I per minute. The rescue operation was started in the mine and special rescue groups were called. On $3^{\text {rd }}$ August 1977, the inrush of water was of 500 I per minute. The salt mining was completely suspended. In the night from 4 to 5 August, about 1 a.m., the inrush of water bumped up to 2,000 $\mathrm{m} 3$ per minute. The last miners left the mine and the uncontrolled flooding started. The inrush of water into the mine caused the biggest surface mining failure in Poland which has never been listed in the Polish mining history. On 5th August 1977, around 2.00 a.m, the water leaked from the surface reservoir, the remains of the ancient gypsum mine. It caused the ground ruptures. In result, many garages in Karol Świerczewski Street, in the proximity of ancient gypsum mine fell in (Figure 2).

The evacuation operations of the inhabitants from the Górnicza, Pocztowa, Dworcowa and Świerczewski Street was organized by the voivode of Pila. The mine office, the kindergarten, the post office the pharmacy and the medical center were also evacuated. The church was closed. In total, 321 people from 21 buildings quitted Wapno. The Gniezno-Nakło (on the river Noteć) railway transport on Damasławek-Kcynia line were interrupted. In the night from 15 to 16 August, the soil cracks and slipping in the area of the Ogrodowa Street took place. Another evacuation operations of 113 inhabitants from 7 buildings located in Ogrodowa and Stanisław Staszic Street were launched. In mid-August, the works of 6 meters long pipeline construction from the Czeszewski lake to Wapno was started. It served to further flooding of the salt mine and gypsum cap rock.

In the same time, the Minister of Chemical Industry created the Group to manage the issues related to the flooding of the underground excavations of the Tadeusz Kosciuszko Salt Mine in Wapno. The first miners left Wapno to seek jobs in Śląsk. On 1st and $15^{\text {th }}$ September, two major groups of miners (around 150 people) found work in Salt Mine in Kłodawa (Salt Mine..., 2018). The last one took over the production processes of Wapno mine (part of the miners found shelter in Lubińsko-Głogowski copper district. 


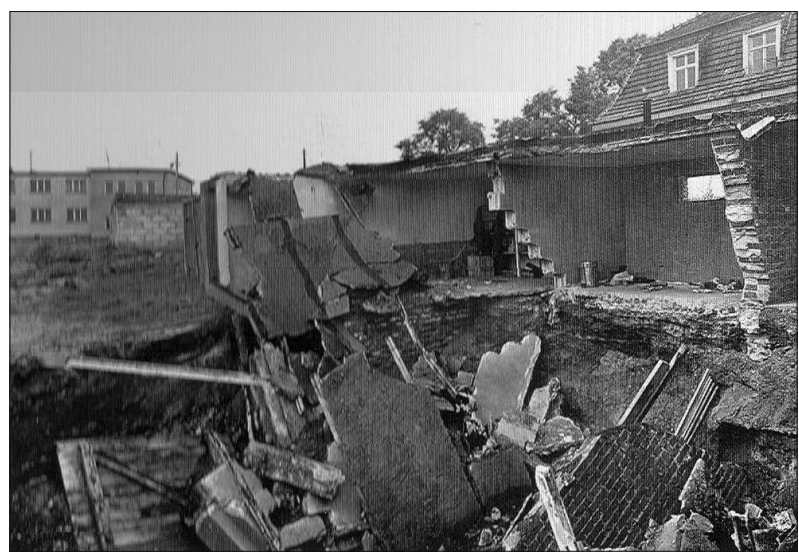

Figure 2. The garages in Karol Świerczewski Street, the $5^{\text {th }}$ August 1977

Source: Przesławski, Ryska, Wojciński (2011), p. 53.

On 8th September, another soil movements happened. Around 11.00, in 26, Świerczewski Street (near a residential building) a sink-hole was created (with the diameter of 3.5 meters and the depth of 3 meters). It engulfed part of the street and a pavement with a tree (Figure 3 ). It caused the cracking of the water pipeline stretched along the street. The sink-hole was buried. In that area, 20 inhabitants from 2 buildings were evacuated. The same day, around 15.00, at the intersection of Pocztowa and Górnicza Streets, another sink-hole was created (with the diameter of 1.5-2 meters and the depth of 1.8 meters). It was also buried. (Lisiecki, 2007, p. 112).

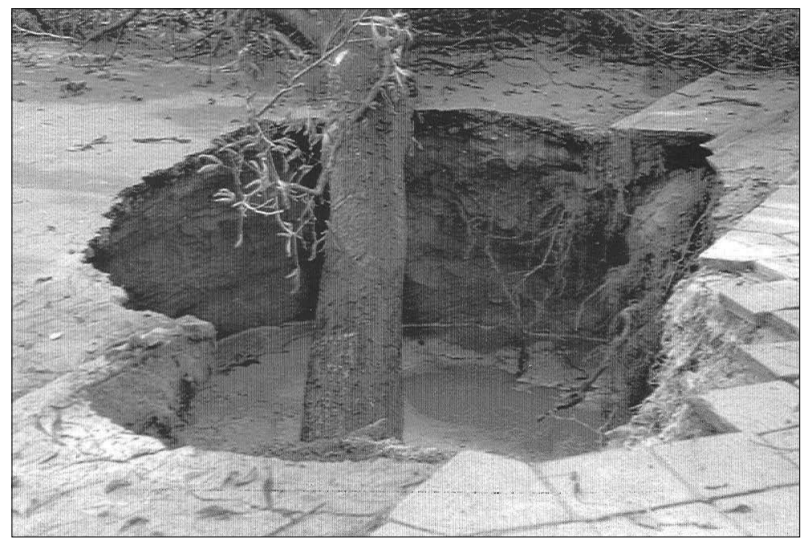

Figure 3. The sink-hole which engulfed part of the Świerczewski Street and a pavement with a tree

Source: Przesławski, Ryska, Wojciński (2011), p. 97.

The most enormous damages were reported on 28th September when another soil deformation took place causing one more sink-hole in the center of Wapno. It swept over the residential buildings and the northern part 
of the railway station. The same day, around 8.30, close to the residential building in 9, Obrońcy Stalingradu Street, a sink-hole in form of a crater with the diameter of 32 meters and the depth of 20 meters was created. It swept over the front wall of a block of flats and it broke it (Figure 4).

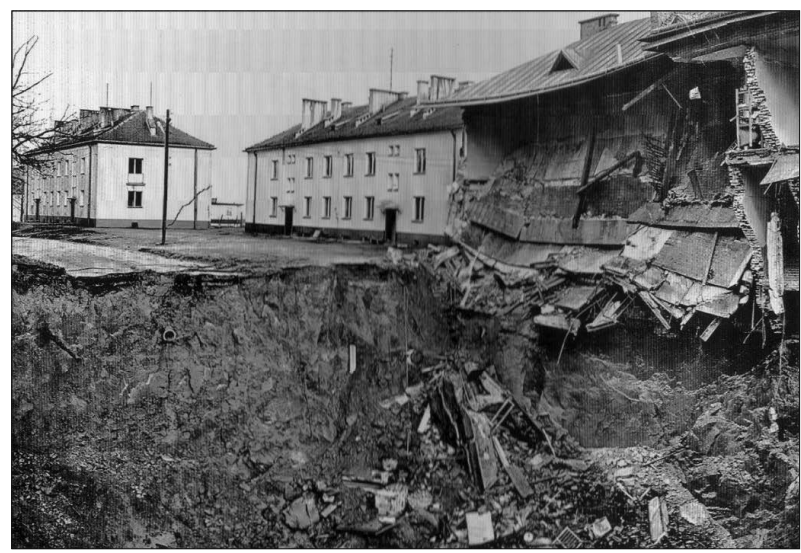

Figure 4. Obrońcy Stalingradu Street 9 , the 28th of October 1977

Source: Przesławski, Ryska, Wojciński (2011), p. 78.

The railway tracks going through Wapno were also demolished (Figure 5).

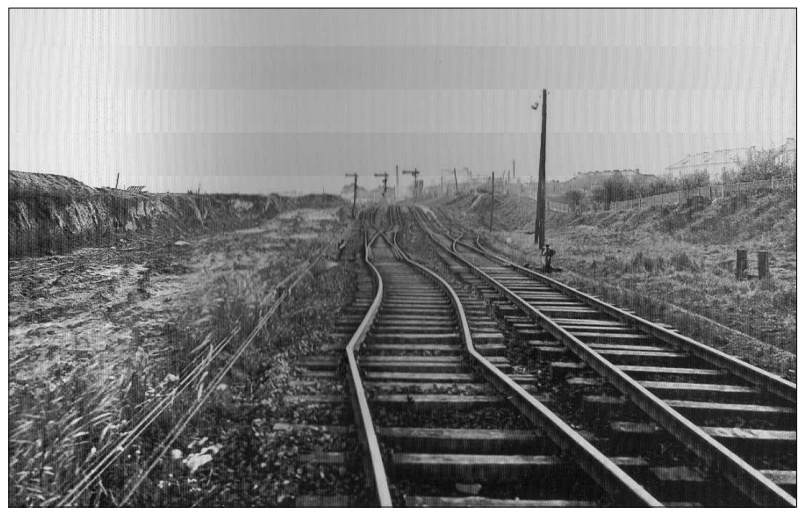

Figure 5 . The railway tracks in Wapno

Source: Przesławski, Ryska, Wojciński (2011), p. 107.

The biggest evacuation operations took place. Another 900-1,000 people quitted Wapno. The next day, the police from the police school in Pila and the military forces were sent on the spot (Lisiecki, 2007, p. 113). The surface soil movements were also reported along the Obrońcy Stalingradu, Staszic and Ogrodowa Streets. 
On 29th December, in the Świerczewski Street, the marks of surface soil movements were observed. The sink-hole in the Obrońcy Stalingradu street was extended. On 16th January 1978 the strong soil movements were spotted and they brought damages of few blocks of flats and the diary situated at Stanisław Staszic Street. The Obrońcy Stalinigradu Street and the deformed railway tracks declined. The soil cracks 1 meter wide and 1 kilometer long appeared. The cliffs with the depth of 3.5 meter were created. On 30th June 1978, the controlled flooding of the salt mine was terminated. In August, the Council of Ministers of People's Poland passed the law no 120/78 about the liquidation of the catastrophe effects in the Tadeusz Kosciuszko Salt Mine in Wapno. The liquidation was financed by the mine damages, land remediation and development funds.

As a result of the catastrophe, 42 buildings including 23 blocks of flats, houses and 19 other properties situated along the streets were demolished or damaged. It touched Obrońcy Stalingradu Street, Ogrodowa Street, Pocztowa Street, Mining Street and Karol Świerczewski Street (first four streets don't exist anymore). The railway tracks were destroyed. Wapno lost the half of its inhabitants (about 1,500 people). Fortunately, nobody was injured due to the disaster. The evacuated inhabitants obtained new houses and jobs mostly in the Piła voivodeship. The majority of inhabitants (about 900) found their new homes in Pila. The others were located in Wagrowiec, Złotów, Trzcianka, Czarnków, Wronki and Gołańcz. Kłodawa (the ancient Konin voivodeship) and Szubin (Bydgoszcz voivodeship) were two towns outside the Pila voivodeship where the displaced people from Wapno were moved.

Among others, the first cause of the Wapno mine disaster is considered today the fracture of the optimum thickness of the salt protection shelf (it was counted as water danger) while exploiting the best quality salt at the third mine level. There are voices that if the salt hadn't been excavated at the third mine level, the mine would have never been flooded. The third level was the mine security border. It should be mentioned that during the World War II, the Germans knew about this fact and they had never decided to excavate salt from this mine level. The rock shooting also had bad influence on the strength of the rocks and on the lack of the coordination in exploitation of both gypsum and salt mine (Lisiecki, 2007, p. 119).

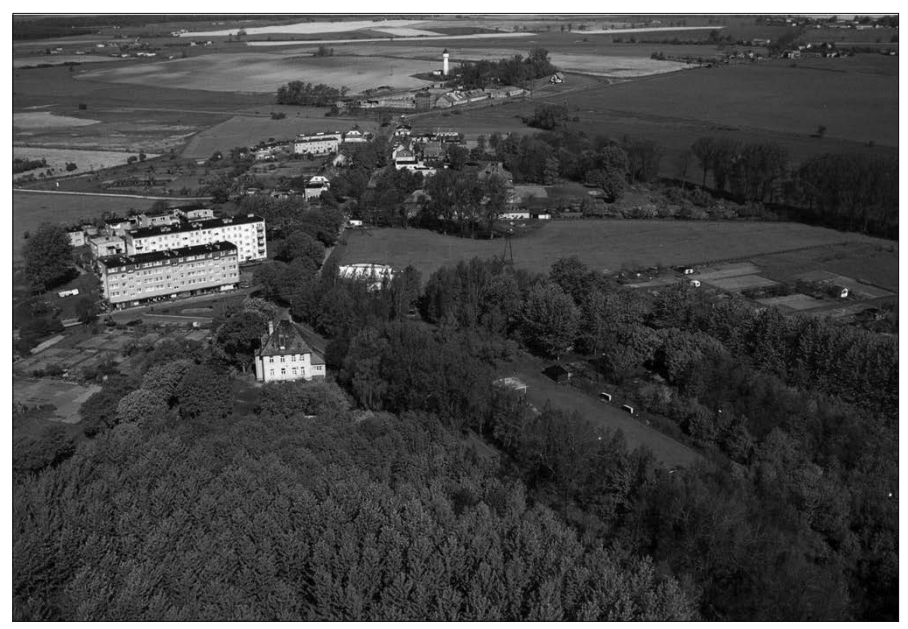

Figure 6 . Currently, the Wapno mining disaster area is covered by a forest

Source: Przesławski, Ryska, Wojciński (2011), p. 132. 
As indicated by the rest, as a result of the mining catastrophe, Wapno lost about half of its inhabitants. The data published in December 2018 testifies that there are 1,650 inhabitants in Wapno.

The financial losses resulting from the biggest surface mining catastrophe haven't still been counted.

Wapno has never regained its prosperity for 41 years elapsed from the catastrophe. Apart from the demolition of damaged blocks of flats and the forestation of the area, the complex revitalization of Wapno has never took place either. Today, in the mining disaster area that is the former housing estate, the Obrońcy Stalingradu Ogrodowa, Staszic and Świerczewski streets doesn't exist anymore and the forest grows (Figure 6).

Nowadays, in the area of the former salt mine, few small active production service companies are active.

The Wapno mining catastrophe warns against resulting in hold-up problem in managing mineral sources. The equilibrated mineral excavation should be led. Its exploitation couldn't be done at any cost as to leave it for future generations.

\section{Conclusions}

After the first stage of the catastrophe (August and September 1977), a construction plan of a new housing estate outside the mining area was proposed. Because of the another rock bumps (October 1977, January 1978), the plans had never been realized, in spite of the land preparations and planned works. After the catastrophe, in the period 1978-1985, the production profile of the company changed for The Tadeusz Kościuszko Salt Mine and the Renovation Company (even if the salt excavations were stopped). The wagons used for Sulphur and bulk cement transport were maintained there. In the years, 1980-1981, the technical- economic plans of the Metal Industry in Wapno were elaborated. The investment should have been realized from central funds. Due to the political and economic situation at the beginning of the 80', it had never been done. There were various conceptions of land development of that ancient salt mine. The factory of rolling-element bearings in Poznan was getting ready to open there its branch. The "Pollena" Factory planned the production of toothpaste and cream tubes. A Swedish cosmetic company was even interested. The numerous propositions of adaptation of the company to other than a mining industry were issued of propaganda. From 1984, wagon bodies to transport chemical products were renovated there (Lisiecki, 2007, p. 122). In the years 1983-1984, the experimental-production installation of autoclaved gypsum was constructed in that area. In 1985, 2000 tons of alpha gypsum was produced and sold. The raw material came from the gypsum mine in Niwice in Lower Silesia. In Wapno, there were plans to exploit the high quality gypsum again. For security and financial reasons, the project was abandoned. In the years 1978-1991, the factory counted between 250 and 280 employees. In 1991, the company as national one was liquidated. In 1994, the first application to the Commercial Court in Pila was made for the company bankruptcy. It was dismissed. New owner of the company was wanted. The potential buyers were coming on the spot to see the plant but while they got to know that the mining damages could repeat in the future, they were giving up (Lisiecki, 2007, p. 124). The liquidator was systematically selling the assets of the company. With time, the liquidator was replaced by a bankruptcy trustee who distributed the remaining assets and the immobility. In December 1998, the Commercial Court in Pila, removed the company from company register. Nowadays, in the area of the ancient Wapno salt mine, few production service companies are prospering. Minor mining damages continued few times in Wapno. The most considerable one occurred in 2007 in the area of the ancient gypsum mine. The settlement is still the active zone and at risk of mining damages, particularly in the vicinity of the ancient salt mine and the ancient gypsum mine. 
The best chance for Wapno development seems to be turism based on the mining past, analogically to the one flourishing in the ancient mining centers as Wieliczka, Bochnia, Wałbrzych and Katowice.

The development of touristic services could bring about the rise of Wapno. One of the ideas is utilisation of two monuments of the former salt mine, which are steam mill and the building with steam winding engine in order to create the Wapno Salt Mine museum as well as the Polish gypsum and salt mining and salt grottos museum (memorial room).The educative touristic path in the disaster area that is, in the same time, the former housing estate area is to be created. There would be commemorative plaques with building images and their descriptions fixed along the inexisting streets. There are plans to raise European funds to make the project assumption work as part of bilateral Polish-German project.

\section{References}

Boras, Z. (1963). Rozwój historyczny Wapna i okolicy. In: S. Kopeć (ed.), Kopalnia Soli w Wapnie. Rys historyczny (pp. 38-64). Poznań: Wydawnictwo Poznańskie.

Domichowski, F., Günther, M., Jankowski, Z. (1963). Rozwój kopalni w latach 1911-1961. In: S. Kopeć (ed.), Kopalnia Soli w Wapnie. Rys historyczny. (pp. 78-112). Poznań: Wydawnictwo Poznańskie.

Grabowski, Z. (2013). Wpływ górnictwa gipsowego i solnego na rozwój Wapna i okolicy. Kronika Wielkopolski, 2, 138-148.

Lisiecki, M. (2007). Kopalnia wczoraj i dziś. Zarys dziejów Kopalni Soli w Wapnie 1911-1991. Wagrowiec: Wydawnictwo ZPW „M-Druk”. Łuczak, C. (1959). Górnictwo wielkopolskie w latach 1815-1918. Roczniki Dziejów Społecznych i Gospodarczych, XX, 107-158.

Muszyński, W. (1999a). Kopalnia soli w Wapnie. Ziemia Wągrowiecka, 1, 11-46.

Muszyński, W. (1999b). Kopalnia gipsu w Wapnie. Ziemia Wąrowiecka, 1, 47-53.

Przesławski, L, Ryska, M., Wojciński, M. (2011). 100 lat Kopalni Soli w Wapnie 1911-2011 w fotografii. Wagrowiec: Wydawnictwo ZPW „M-Druk".

Salt Mine in Wapno (2018). Retrieved from: http://palukitv.pl/teksty/poznajemy-paluki-i-zm/1030-wapno-sol-i-gips.html.

Skoczylas, J. (2011). Petrografia wobec wyzwań współczesnej turystyki i przemysłu kamieniarskiego. Górnictwo i Geologia, 6 (4), 71-82.

Cite this article aS: Małachowski, K. (2018). The biggest surface mining disaster in Poland and its economic results. European Journal of Service Management, 4 (28/2), 247-255. DOI: 10.18276/ejsm.2018.28/2-31. 